\title{
Proline metabolism and transport in plant development
}

\author{
Silke Lehmann • Dietmar Funck • László Szabados • \\ Doris Rentsch
}

Received: 15 December 2009/ Accepted: 10 February 2010/Published online: 5 March 2010

(C) Springer-Verlag 2010

\begin{abstract}
Proline fulfils diverse functions in plants. As amino acid it is a structural component of proteins, but it also plays a role as compatible solute under environmental stress conditions. Proline metabolism involves several subcellular compartments and contributes to the redox balance of the cell. Proline synthesis has been associated with tissues undergoing rapid cell divisions, such as shoot apical meristems, and appears to be involved in floral transition and embryo development. High levels of proline can be found in pollen and seeds, where it serves as compatible solute, protecting cellular structures during dehydration. The proline concentrations of cells, tissues and plant organs are regulated by the interplay of biosynthesis, degradation and intra- as well as intercellular transport processes. Among the proline transport proteins characterized so far, both general amino acid permeases and selective compatible solute transporters were identified, reflecting the versatile role of proline under stress and non-stress situations. The review summarizes our current
\end{abstract}

\section{S. Lehmann · D. Rentsch $(\bowtie)$}

Institute of Plant Sciences, University of Bern,

Altenbergrain 21, 3013 Bern, Switzerland

e-mail: doris.rentsch@ips.unibe.ch

S. Lehmann

e-mail: silke.lehmann@ips.unibe.ch

\section{Funck}

Department of Plant Physiology and Biochemistry,

Konstanz University, Universitätsstraße 10,

78464 Konstanz, Germany

e-mail: dietmar.funck@uni-konstanz.de

\section{Szabados}

Institute of Plant Biology, Biological Research Center,

Temesvári krt. 62, 6726 Szeged, Hungary

e-mail: szabados@brc.hu knowledge on proline metabolism and transport in view of plant development, discussing regulatory aspects such as the influence of metabolites and hormones. Additional information from animals, fungi and bacteria is included, showing similarities and differences to proline metabolism and transport in plants.

Keywords Proline - Plant - Metabolism - Transport . Regulation · Development

\section{Introduction}

The amino acid proline contains a secondary amino group and is thus unique among the proteinogenic amino acids. Proline plays a crucial role for cellular metabolism both as a component of proteins and as free amino acid. Due to its cyclic structure, proline has a restricted conformational flexibility, which determines the arrangement of the peptide chain around it, and as a consequence leads to stabilization or destabilization of secondary structures of protein conformation. In addition to its role in primary metabolism as a component of proteins, the free amino acid proline is one of the most widely distributed compatible solutes that accumulate in plants and bacteria during adverse environmental conditions such as drought, high salinity or low temperatures (Bohnert et al. 1995; Sleator and Hill 2002). The role of proline as compatible solute and the importance of proline metabolism under stress conditions in plants have been a field of intense research and the current state of knowledge including novel findings and open questions is covered by several recent and excellent reviews (Kavi Kishor et al. 2005; Verbruggen and Hermans 2008; Szabados and Savouré 2010). Although these stress-related issues cannot be ignored, the present review will focus primarily on the 
role of proline during plant development as well as on regulation of proline metabolism and transport.

\section{Proline biosynthesis}

The anabolic branch of proline metabolism was first described in bacteria, where proline is synthesized from glutamate in three steps. Glutamate is phosphorylated by $\gamma$-glutamyl kinase using ATP and the resulting glutamyl- $\gamma$ phosphate is reduced to glutamic- $\gamma$-semialdehyde (GSA) by glutamic- $\gamma$-semialdehyde dehydrogenase. The reversible cyclization of GSA to $\Delta^{1}$-pyrroline-5-carboxylate (P5C) is spontaneous and followed by the reduction of $\mathrm{P} 5 \mathrm{C}$ to proline, catalysed by $\Delta^{1}$-pyrroline-5-carboxylate reductase (P5CR) using NADPH (Csonka 1989). Proline biosynthesis in other kingdoms follows the same pathway, albeit differences exist. The $\gamma$-glutamyl kinase and $\gamma$-glutamyl phosphate reductase enzymes are conserved in bacteria ( $P$ roB , ProA) and yeast (PRO1, PRO2), whereas in plants and animals both activities are combined in a bifunctional enzyme called $\Delta^{1}$-pyrroline-5-carboxylate synthetase (P5CS) that requires ATP as well as NADPH (Fig. 1; Tomenchok and Brandriss 1987; Csonka 1989; Hu et al. 1992; Aral et al. 1996). Activities of $\gamma$-glutamyl kinase in bacteria and yeast and of P5CS in plants represent the ratelimiting step of proline biosynthesis and are regulated through allosteric inhibition by the endproduct proline (Csonka et al. 1988; Hu et al. 1992; Sekine et al. 2007). One P5CS gene has been identified in man and mouse, which, due to alternative splicing, encodes two P5CS isoforms that differ in sensitivity to ornithine inhibition (Aral et al. 1996; Hu et al. 1999). Mutations in the human P5CS gene lead to metabolic abnormalities resulting in multiple disorders such as neurodegeneration, cataracts and connective tissue disorder, suggesting that P5CS is essential for proline and/or arginine supply (Baumgartner et al. 2005; Bicknell et al. 2008; Hu et al. 2008a). Plant genomes usually contain two homologous genes that encode P5CS proteins, e.g. Arabidopsis, Medicago sativa, Medicago truncatula and Oryza sativa (Strizhov et al. 1997; Ginzberg et al. 1998; Hien et al. 2003; Armengaud et al. 2004). The expression patterns indicate that P5CS paralogs have different functions during plant life and development, although the specific roles differ among plant species (see Kavi Kishor et al. 2005 for review). Analysis of Arabidopsis $p 5 c s 1$ and $p 5 c s 2$ knockout mutants confirmed the non-redundant function of the isoforms for plant development and stress tolerance (Székely et al. 2008; see below). Recent phylogenetic analysis suggested that P5CS genes underwent duplication several times independently after monocot and dicot divergence, allowing for the observed functional specialization (Turchetto-Zolet et al. 2009). The sequence identity of plant P5CS proteins ranges

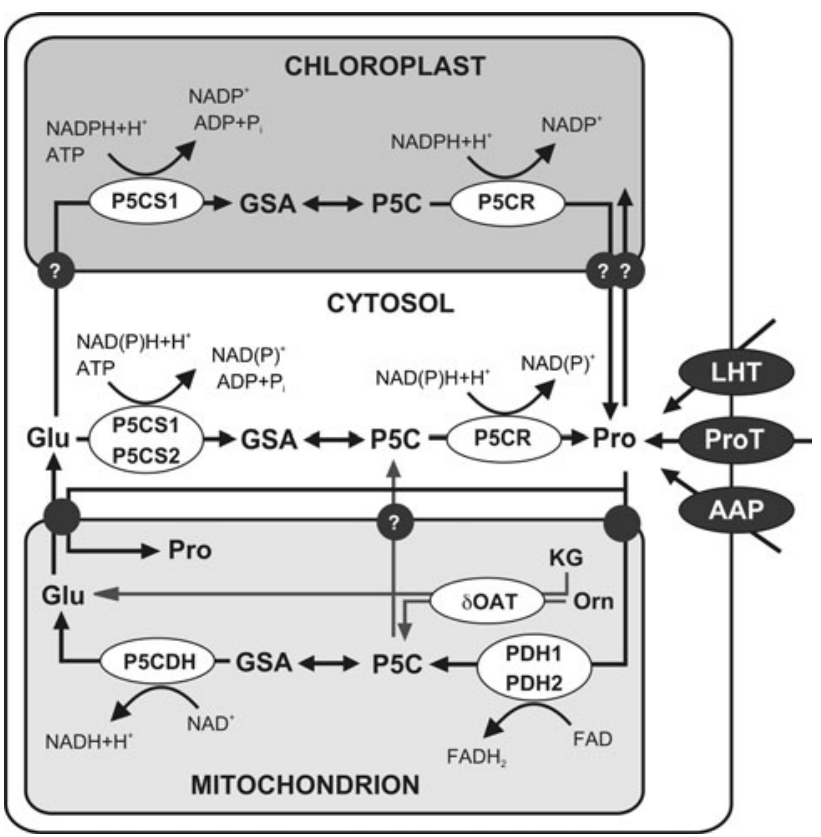

Fig. 1 Model of proline metabolism and transport in Arabidopsis cells. Substrates are shown in black: Pro proline, Glu glutamate, Orn ornithine, P5C pyrroline-5-carboxylate, GSA glutamic- $\gamma$-semialdehyde, $K G \alpha$-ketoglutarate. Enzymes are encircled: P5CS P5C synthetase, $P 5 C R$ P5C reductase, $P D H$ proline dehydrogenase, $P 5 C D H$ P5C dehydrogenase, $\delta O A T$ ornithine- $\tilde{\delta}$ aminotransferase. Transporters are shown as dark grey circles: AAP amino acid permease, ProT proline transporter, $L H T$ lysine-histidine transporter, transporters that have only been described physiologically are shown as circles without label; proposed transporters are indicated by a question mark

between 65 and $98 \%$ in different species (Szabados, unpublished).

For the second enzyme of proline biosynthesis, P5CR, two isoforms were biochemically identified in pea and spinach, although it is currently unclear, whether the two isoforms originate from one or two genes (Williamson and Slocum 1992; Murahama et al. 2001). In the Arabidopsis genome, P5CR is encoded by a single gene, though alternative splicing might generate two different proteins (Verbruggen et al. 1993; Hare and Cress 1996; http:// fgcz-atproteome.unizh.ch; http://www.arabidopsis.org). The human genome contains two P5CR and one P5CR-like gene and although localization in the cytosol and/or loose association with the cytosolic side of the outer mitochondrial membrane was described, for one P5CR isoform colocalization with mitochondrial P5CS was recently shown (Dougherty et al. 1992; Hu et al. 2008b; Reversade et al. 2009). In plants, P5CR activity has been detected in the cytosol and in plastids of several plant species, and also the P5CS isoforms differ in their distribution between these two compartments, depending on environmental conditions (see Szabados and Savouré 2010 for review).

In an alternative pathway of proline synthesis, the activity of ornithine- $\delta$-aminotransferase ( $\delta \mathrm{OAT}$ ) converts ornithine 
and $\alpha$-ketoglutarate to P5C and glutamate by transamination (see Stránská et al. 2008 for review). Arabidopsis mutants lacking $\delta \mathrm{OAT}$ activity were unable to mobilize nitrogen from arginine or ornithine but showed normal proline accumulation, supporting a role for $\delta \mathrm{OAT}$ mainly in arginine degradation (Funck et al. 2008). The localization of $\delta \mathrm{OAT}$ in mitochondria probably generates a barrier to direct utilization of $\delta \mathrm{OAT}$-generated P5C by P5CR, which is localized in the cytosol or in plastids (Funck et al. 2008). In intact plant mitochondria fed with ornithine very little release of P5C was detected, supporting the concept that glutamate is an obligate intermediate in the conversion of ornithine to proline in plants (Elthon and Stewart 1982). The situation seems to be different in mammalian cells, where 8OAT, P5CS and at least one P5CR isoform might colocalize in mitochondria (Aral and Kamoun 1997; Hu et al. 2008b; Reversade et al. 2009). In humans, $\delta$ OAT deficiency is associated with high ornithine levels in blood and urine (Ramesh et al. 1991). Patients suffer from gyrate atrophy, a degenerative disease of the choroid and retina of the eye that leads to blindness (Mitsubuchi et al. 2008).

\section{Degradation of proline}

Proline degradation in eukaryotes takes place in mitochondria and thus in plants is spatially separated from the biosynthetic pathway. Proline catabolism starts with the oxidation of proline to $\mathrm{P} 5 \mathrm{C}$ by proline dehydrogenase (PDH), using FAD as cofactor. $\mathrm{P} 5 \mathrm{C}$ is subsequently converted to glutamate by pyrroline-5-carboxylate dehydrogenase (P5CDH) using $\mathrm{NAD}^{+}$(Fig. 1). Whereas in eukaryotes two enzymes catalyse these subsequent steps in proline degradation, in bacteria both mono- and bifunctional enzymes exist (Tanner 2008). Two homologous genes have been identified to encode proline dehydrogenases in Arabidopsis and tobacco (Mani et al. 2002; Ribarits et al. 2007; Verbruggen and Hermans 2008; Funck, unpublished), while data from other plant species are scarce. In contrast, the enzyme catalysing the second step of proline degradation $(\mathrm{P} 5 \mathrm{CDH})$ is encoded by a single copy gene in all monocot and dicot species analysed so far (Deuschle et al. 2001; Ayliffe et al. 2005; Mitchell et al. 2006). Biochemical analysis revealed the presence of two P5CDH activities with slightly different characteristics in Nicotiana plumbaginifolia and Zea mays (Elthon and Stewart 1982; Forlani et al. 1997). At present it is not clear if both activities arise from a single gene or if a second $\mathrm{P} 5 \mathrm{CDH}$ gene is present in these species.

\section{Proline toxicity}

Despite the essential function of proline in primary metabolism and the accumulation of large amounts of proline in stressed plant tissues, exogenous supply of proline to non-stressed plants causes toxic effects (Bonner et al. 1996; Hellmann et al. 2000; Hare et al. 2002). Symptoms of proline intoxication included alteration in chloroplast and mitochondrial ultrastructure as well as several features of programmed cell death (Hare et al. 2002; Deuschle et al. 2004). In Arabidopsis mutants deficient in PDH1 or P5CDH, proline supply inhibited de-etiolation and caused an early arrest of seedling development (Nanjo et al. 2003; Deuschle et al. 2004; Miller et al. 2009; see Verbruggen and Hermans 2008 for review).

In human cell cultures, both $\mathrm{PDH}$ and $\mathrm{P} 5 \mathrm{CDH}$ are direct targets of the central apoptotic integrator p53, whereby $\mathrm{PDH}$ has pro-apoptotic activity, while $\mathrm{P} 5 \mathrm{CDH}$ counteracts induction of apoptosis (Donald et al. 2001; Yoon et al. 2004; Phang et al. 2008). Induction of apoptosis was attributed to ROS formation by misdirected electrons from $\mathrm{PDH}$ and rapid cycling of proline and P5C between $\mathrm{PDH}$ and P5CR in mitochondria. A similar cycle was recently proposed for plants, based on the observation that overexpression of $\mathrm{PDH}$ or deficiency in $\mathrm{P5CDH}$ caused mitochondrial ROS formation (Miller et al. 2009). It remains to be investigated whether the intact mitochondrial membrane constitutes an efficient barrier which prevents cycling of proline and $\mathrm{P} 5 \mathrm{C}$ in plants, possibly controlled by a to date hypothetical P5C transporter. Further information on the role of proline metabolism as a redox shuttle between different compartments is covered in a recent review by Szabados and Savouré (2010).

\section{Proline in plant development}

The level of free proline varies considerably in different plant organs and is usually higher in reproductive organs than in vegetative tissues (Chiang and Dandekar 1995; Fujita et al. 1998; Armengaud et al. 2004). High concentrations of proline have been reported in plant organs during endogenously controlled dehydration, e.g. in seeds or pollen (see below). Furthermore, a high leaf-to-root ratio for proline has been found in several plant species including Arabidopsis, lentil and common bean (Hua et al. 1997; Sánchez et al. 2001; Misra and Saxena 2009). The amount of free proline in the leaf decreases during leaf maturation in Vicia faba and Brassica juncea (Venekamp and Koot 1984; Madan et al. 1994). Within the leaf blades of Chrysanthemum indicum, proline shows an uneven distribution pattern (Amberger-Ochsenbauer and Obendorfer 1988) as was also detected between lower epidermis and the rest of the leaf in Arabidopsis (Lehmann and Rentsch, unpublished). In barley, the preferential accumulation of proline in epidermis and vascular bundles was only observed under stress conditions (Zúñiga et al. 1989). The 
biological significance of these differences has not been investigated so far.

Being a precursor for hydroxyproline-rich proteins, proline is an essential cell wall component. The antisense inhibition of Arabidopsis AtP5CS1 led to malformation of leaf parenchyma, epidermal and vascular tissues accompanied by a decrease in proline and hydroxyproline content of the cell wall (Nanjo et al. 1999). This phenotype was not observed for atp5cs 1 knockout mutants, suggesting that it might partially be attributed to impaired expression of AtP5CS2 due to high sequence similarity of the two P5CS genes (Székely et al. 2008). On the other hand, an increased proline synthesis was shown to affect leaf size and tissue formation as well, suggesting that proline homeostasis has to be tightly controlled (Mauro et al. 1996; Trovato et al. 2001; Mattioli et al. 2008). Interestingly, the expression of 35S:AtP5CS1 resulted in a decrease of AtP5CS1 transcript level at later stages of plant development, leading to a reduction of leaf proline content and stunted growth similar to the phenotype of AtP5CS1 antisense lines (Mattioli et al. 2008). High expression of AtP5CS2 in leaf primordia and callus cells indicates that rapidly dividing and growing cells have a high demand for proline (Strizhov et al. 1997; Székely et al. 2008).

\section{Proline during flower development}

First indications for a role of proline in flower formation came from studies using transgenic plants with enhanced or repressed P5CS expression. Kavi Kishor et al. (1995) reported that tobacco plants constitutively expressing moth bean VaP5CS developed more flowers under high salinity conditions than the wildtype, although this difference might be attributed to the protective effects of proline as a compatible solute. Furthermore, Arabidopsis plants carrying an AtP5CS1 antisense construct displayed an impaired elongation of the inflorescence internodes and reduced fertility in the absence of stress (Nanjo et al. 1999). Externally supplied L- but not D-proline could suppress the mutant phenotype (Nanjo et al. 1999). In axenic cultures of moth bean, the exogenous application of proline caused changes of flowering time, the length of the flowering period and the number of flowers (Saxena et al. 2008).

A stimulating effect on floral transition was also observed in tobacco plants, where expression of RolD, a bacterial enzyme catalyzing the direct conversion of ornithine to proline, resulted in early bolting, precocious flowering and the enhanced formation of axillary flower buds (Mauro et al. 1996; Trovato et al. 2001). The P5CSdependent proline synthesis from glutamate was associated with flower development in several studies. In Arabidopsis, expression of AtP5CS-GFP fusion proteins under the control of their native promoters revealed that in flowers
AtP5CS1-GFP was present exclusively in anthers, whereas AtP5CS2-GFP was found in inflorescence meristems, flower primordia and flower buds (Székely et al. 2008). However, in situ mRNA hybridization analysis detected indistinguishable expression patterns for both P5CS genes in all tissues tested, including vegetative and floral shoot apical meristems as well as axillary meristems (Mattioli et al. 2009b). Arabidopsis AtP5CS2 is an early target gene of the transcription factor CONSTANS that promotes flowering in response to day length (Samach et al. 2000). Moreover, the overexpression of AtP5CS1 caused an early flowering phenotype, further supporting the hypothesis that the proline level is implicated in floral transition (Mattioli et al. 2008). Since an atp5cs 1 T-DNA insertion mutant has a late flowering phenotype that was enhanced when atp $5 c s 1$ plants were heterozygous for an atp $5 c s 2$ insertion, both P5CS genes appear to be involved in flowering control (Mattioli et al. 2009a, b).

The analysis of numerous plant species revealed that proline is one of the most abundant amino acids in angiosperm pollen, while it is less abundant in gymnosperm pollen (Khoo and Stinson 1957; Krogaard and Andersen 1983; Lansac et al. 1996; Nepi et al. 2009). It was suggested that proline might act as a compatible solute in the dehydrated pollen grain or function as a source of energy and as metabolic precursor during pollen germination (Zhang and Croes 1983; Mutters et al. 1989; Schwacke et al. 1999). Interestingly, the high proline content of tomato pollen does not correlate with the relatively low abundance of P5CS transcripts (Fujita et al. 1998). In contrast, Arabidopsis P5CS1-GFP was detected in the pollen grains, indicating that there might be species-related differences (Székely et al. 2008). In tobacco, proline is the most abundant amino acid in mature anthers (Horner and Pratt 1979). Pollen of Arabidopsis and tobacco contains high amounts of proline despite the elevated expression level of $P D H$, indicating that $P D H$ transcripts might accumulate without immediate translation into protein, as appears to be the case for numerous mRNA species present in pollen (Mascarenhas 1993; Nakashima et al. 1998; Ribarits et al. 2007; Lehmann and Rentsch, unpublished).

Pollen is symplasmically isolated and therefore dependent on membrane transport to sustain its development. Transcriptome analysis suggested that transporter genes become overrepresented as the pollen matures and identified substantial expression of the proline transporter AtProT1 in mature pollen grains (Honys and Twell 2004; Bock et al. 2006). Since the amino acid level in mature pollen of atprotl knockout plants is unchanged, it is at present not clear to which extent import and endogenous biosynthesis contribute to proline accumulation in Arabidopsis pollen (Lehmann and Rentsch, unpublished). 
Proline is also found in foliar, extrafloral and floral nectar where it is suggested to play a role in taste, pollinator attraction, egg laying in honeybees, insect feeding behaviour and serves as energy source for insects (Carter et al. 2006; Nepi et al. 2009).

Proline during seed development

Immature seeds of Vicia faba accumulated proline before ripening, leading to the assumption that proline might be important for the development of generative organs (Venekamp and Koot 1984). Several studies reported a high proline level in Arabidopsis seeds (Chiang and Dandekar 1995; Schmidt et al. 2007), although data from other plant species are scarce. However, genes encoding enzymes of proline metabolism are expressed during seed development of various plants, including Arabidopsis, tomato, Medicago truncatula and rice (Verbruggen et al. 1993; Fujita et al. 1998; Armengaud et al. 2004; Hur et al. 2004). The antisense repression of AtP5CS1 caused a delay in radicle emergence during Arabidopsis seed germination, suggesting that proline synthesis might replenish the $\mathrm{NADP}^{+}$pool and therefore activate the oxidative pentose phosphate pathway (Hare et al. 2003). In Arabidopsis, concomitant expression of genes for proline synthesis $(P 5 C S, P 5 C R)$ and proline degradation $(P D H, P 5 C D H)$ has been repeatedly demonstrated during seed development, raising the question about a possible function of proline cycling (Verbruggen et al. 1993, 1996; Hua et al. 1997; Deuschle et al. 2004; Székely et al. 2008). While the distribution of P5CS1 and P5CS2 transcripts appears to overlap during embryogenesis, the expression of P5CSGFP fusion proteins revealed a different subcellular localization of the two isoforms (Székely et al. 2008; Mattioli et al. 2009b). Both P5CS-GFP fusion proteins were detected throughout all stages of embryogenesis, but P5CS2-GFP was found in the cytoplasm while P5CS1-GFP formed a dotted pattern in the embryo that did not colocalize with chloroplasts, mitochondria or nuclei (Székely et al. 2008). P5CS2 appears to be more important for seed development, since an insertion in the AtP5CS2 gene causes embryo abortion, while atp 5cs 1 mutants are able to produce viable seeds (Székely et al. 2008; Mattioli et al. 2009b). Embryo lethality in heterozygous atp 5cs2 plants might be caused by premature desiccation of homozygous embryos that develop more slowly than wildtype or heterozygous embryos (Funck, unpublished). The presence of external proline allowed the rescue of homozygous atp $5 \mathrm{cs} 2$ mutant embryos in axenic culture, which developed to fertile plants that produced viable seeds under certain conditions (Székely et al. 2008; Funck, unpublished). Detailed analysis of atp $5 c s 2$ embryos revealed an increased frequency of missing or disoriented cell planes as well as polyembryony, a phenotype that could be partially rescued by treatment with $10 \mu \mathrm{M}$ proline (Mattioli et al. 2009b). The reason for the observed malformations is still largely unknown. Mattioli et al. (2009b) showed that exogenous treatment with proline promotes cell division and causes induction of the cell cycle gene $C Y C B 1.1$. P5CR appears to be required during embryogenesis in Arabidopsis as well, since two independent atp5cr T-DNA insertion mutants are embryo lethal (Meinke et al. 2008; http://www. seedgenes.org).

\section{Regulation of proline metabolism}

\section{Light and metabolites}

One of the first factors demonstrated to influence proline accumulation was the intensity and duration of light exposure (Hanson and Tully 1979; Joyce et al. 1984). The level of free proline in leaves was reported to increase in the light and decrease in the dark (Sanada et al. 1995; Hayashi et al. 2000). Light-dependent changes in the availability of reducing equivalents or the oscillation of the relative water content have been suggested to act as regulators of proline levels (Hanson and Tully 1979; Hayashi et al. 2000). Expression analysis revealed that AtP5CS and $A t P D H$ genes are conversely regulated by light and dark conditions, but it is unclear whether this adaptation is attributed to direct light-signalling or light-dependent metabolic or hormonal signals (Hayashi et al. 2000; Ábrahám et al. 2003). In barley, the light-related fluctuations of proline were more pronounced in shoots than in roots, associating this regulatory pathway to photosynthetically active tissues (Sanada et al. 1995).

Photosynthesis increases the level of sugars, whose promoting influence on proline accumulation was demonstrated in several studies (Stewart et al. 1966; Pesci 1993). High external concentrations of sucrose and glucose caused a stronger accumulation of proline in Brassica napus leaf discs than did mannitol or sorbitol (Larher et al. 1993). This regulation is probably due to transcriptional control of proline metabolism enzymes, since the AtP5CS mRNA level increases, whereas AtPDH1 and AtPDH2 expression is repressed by sucrose (Kiyosue et al. 1996; Nakashima et al. 1998; Hellmann et al. 2000; Hanson et al. 2008). However, many studies reporting an enhanced proline accumulation as response to external sugars have been performed using high sugar concentrations, thus osmotic and sugar-derived signals cannot be easily separated (Stewart et al. 1966; Larher et al. 1993; Pesci 1993; Verslues and Bray 2006).

The role of sucrose in the negative regulation of $A t P D H 1$ and $A t P D H 2$ was demonstrated to involve bZIP 
transcription factors (Weltmeier et al. 2006; Hanson et al. 2008). AtbZIP11, whose translation is inhibited by sucrosespecific signalling, was suggested to act upon sucrose partitioning between source and sink tissues (Rook et al. 1998). Later, AtbZIP11 was shown to regulate expression of AtPDH2 (Hanson et al. 2008). AtbZIP53 was shown to control AtPDHI expression preferably as a heterodimer with group-C bZIP proteins (Weltmeier et al. 2006). One of the cis-elements recognized by AtbZIP11 and other group-S bZIP transcription factors was previously identified as proline- or hypoosmolarity-responsive element (PRE) in AtPDH1 and other genes (Satoh et al. 2002, 2004). A promoting effect of proline on $\mathrm{PDHl}$ expression has been demonstrated in several studies (Kiyosue et al. 1996; Peng et al. 1996; Verbruggen et al. 1996; Nakashima et al. 1998). However, the accumulation of proline under stress conditions does not lead to increased $P D H I$ expression, indicating a dominant mechanism that represses $P D H 1$ expression during abiotic stress (Kiyosue et al. 1996; Verbruggen et al. 1996).

The availability of nitrogen has also been demonstrated to affect proline accumulation in several plants species. The proline content in tobacco leaves increases if plants are grown on medium containing high concentrations of $\mathrm{NH}_{4} \mathrm{NO}_{3}$ (Kavi Kishor et al. 1995). In leaves and roots of common bean (Phaseolus vulgaris), $\delta \mathrm{OAT}$ activity was positively correlated with proline concentrations over a broad concentration range of $\mathrm{NH}_{4} \mathrm{NO}_{3}$, whereas P5CS activity was inversely regulated (Sánchez et al. 2001, 2002). It remains an open question if a direct conversion of ornithine to proline without participation of P5CS is possible under conditions of high nitrogen abundance.

\section{Hormones}

The effect of abscisic acid (ABA) on the expression of P5CS and P5CR during abiotic stress has been described in a number of studies and reviewed previously (Savouré et al. 1997; Hare et al. 1999; Verslues and Bray 2006). Chiang and Dandekar (1995) suggested that the endogenously determined desiccation during seed maturation might also involve an ABA-dependent regulation of proline biosynthesis. ABA is a key regulator of seed development, promoting the accumulation of storage and LEA proteins (Finkelstein et al. 2002). The expression of AtP5CS1 and AtP5CS2 genes is strongly and moderately ABA-responsive, respectively (Strizhov et al. 1997; Ábrahám et al. 2003). The salt-dependent induction of AtP5CS expression is reduced in $a b a$ and $a b i l$ mutants, suggesting that ABA and ABI1-dependent signalling are essential for high levels of gene activation (Strizhov et al. 1997). A link between $\mathrm{ABA}$ and proline might also be provided by sugars, as several ABA-deficient or ABA-insensitive mutants are impaired in their response to sugars as well (Gibson 2005).
Verslues and Bray (2006) demonstrated an inhibitory effect of sucrose on ABA-induced proline accumulation and suggested the transcription factor ABI4 to connect ABAand sugar-signalling in the regulation of proline accumulation. Furthermore, the ABA-dependent induction of P5CS1 expression was prevented by pre-treatment with brassinolide, but the physiological role of this effect is still unknown (Ábrahám et al. 2003). During Arabidopsis seed germination, brassinolide and ABA were shown to behave as antagonistic stimuli (Steber and McCourt 2001).

Secondary messengers such as nitric oxide (NO) or reactive oxygen species such as hydrogen peroxide $\left(\mathrm{H}_{2} \mathrm{O}_{2}\right)$ are known to mediate ABA signals and affect proline metabolism under stress conditions (Desikan et al. 2002; Neill et al. 2008; Wang and Song 2008; Yang et al. 2009). In the green alga Chlamydomonas reinhardtii, NO treatment enhanced the copper-induced proline accumulation and increased the expression of P5CS (Zhang et al. 2008). By contrast, the increase of proline levels in Brassica rapa plants under high salinity conditions was less pronounced when plants were simultaneously treated with NO, possibly due to less efficient reduction of PDH activity (López-Carrión et al. 2008). In Arabidopsis, NO donors stimulated P5CSI expression and repressed PDHI expression, while NO scavengers had inverse effects (Zhao et al. 2009). Mutant analyses suggested that nitrate reductase rather than NO synthase is responsible for NO-mediated regulation of proline accumulation and concomitant freezing tolerance (Zhao et al. 2009). A connection between the accumulation of proline and ROS was established studying pathogen interaction in Arabidopsis. Avirulent pathogens induce ROS generation in infected leaves, and local proline accumulation was observed in Arabidopsis challenged with avirulent Pseudomonas syringae strains, though a direct causal relationship has not been demonstrated (Fabro et al. 2004). In maize seedlings, exogenous hydrogen peroxide treatment induced proline accumulation by activation of the biosynthetic pathway, including P5CS, $\delta$ OAT and arginase (Yang et al. 2009).

Another plant regulator that appears to be involved in the regulation of proline metabolism is salicylic acid (SA). Several recent studies reported a promoting effect of SA on proline accumulation even in the absence of stress (Kanade 2008; Yusuf et al. 2008; Misra and Saxena 2009). Treatment with $0.5 \mathrm{mM}$ SA elevated the proline content in the shoots of lentil seedlings by a factor of $4-5$, possibly by enhancing P5CR activity and decreasing the activity of PDH (Misra and Saxena 2009). The impact of SA on proline accumulation was further increased under high salinity conditions, leading to the assumption that the stress-protective effect of SA might partially be achieved via control of proline metabolism (Misra and Saxena 2009). Treatment with SA also increased peroxidase 
activity, as did the exogenous supply of proline (Ötztürk and Demir 2002; Yusuf et al. 2008). Interestingly, the SAassociated regulation of proline metabolism enzymes was largely restricted to the shoots of lentil, whereas the roots showed weak changes for the parameters tested (Misra and Saxena 2009). Likewise, SA treatment increased proline accumulation in barley shoots but not in roots (El-Tayeb 2005). Since SA was also reported to increase photosynthetic rates in several crop species including maize, barley and soybean (Pancheva et al. 1996; Khan et al. 2003; Khodary 2004), these data suggest that SA-mediated signals might regulate proline metabolism in photosynthetically active tissues. Furthermore, SA was demonstrated to be a regulator of flowering time in Arabidopsis (Martínez et al. 2004) and is thus, similar to proline synthesis, associated with reproductive development as well as stress responses. SA signalling is also involved in the induction of the hypersensitive response and P5CS2 expression after infection with avirulent Pseudomonas syringae strains in Arabidopsis (Fabro et al. 2004). Plants with low SA levels due to mutation of EDS5 or overexpression of a bacterial salicylate hydroxylase (NahG) did not show enhanced P5CS2 expression or proline accumulation in response to pathogen attack (Fabro et al. 2004).

\section{Proline transport}

\section{Translocation of proline}

Evidence connecting changes in proline content with transport processes comes from developmental as well as stress-related studies. The proline deposition in the elongation zone of maize roots at low water potential was not achieved by biosynthesis but by an increase in proline transport (Verslues and Sharp 1999). Another study using maize seedlings demonstrated that proline utilization exceeds biosynthesis and that proline, provided by degradation of proline-rich storage proteins of the endosperm, is imported into the seedling (Raymond and Smirnoff 2002). Similarly, the accumulation of proline in maturing grapevine berries was not associated with increased P5CS expression, suggesting a contribution of transport processes (Stines et al. 1999).

Proline has been detected in both phloem and xylem sap in several plant species (Weibull et al. 1990; Bialczyk et al. 2004). The amount of proline in the phloem sap of alfalfa was elevated under water stress, indicating that long-distance transport might be important for stress-related changes in metabolism and/or stress tolerance (Girousse et al. 1996). Girdling experiments revealed increased proline levels in leaves and reduced proline concentrations in sink organs, also suggesting proline translocation from stressed leaves to culms and roots (Tully et al. 1979). However, antisense repression of glutamine synthetase in phloem cells of tobacco led to a reduced proline content in different organs as well as in phloem and xylem cells, indicating that proline might also be synthesized within the phloem cells and directly depends on glutamate availability (Brugière et al. 1999).

\section{Proline transporters}

Plant transporters mediating proline uptake across the plasma membrane have been identified both in the amino acid transporter (ATF) or amino acid/auxin permease (AAAP) family and in the APC (amino acid-polyaminecholine) family (Rentsch et al. 2007; Table 1). Though some members of the cationic amino acid transporters (CATs), belonging to the APC family, transport neutral amino acids, none of them recognizes proline efficiently and therefore their role will not be discussed further (Frommer et al. 1995; Su et al. 2004; Hammes et al. 2006). In the ATF/AAAP family, transporters that recognize proline have been identified in different subfamilies, namely in the amino acid permease (AAP) family, the lysine-histidine transporter (LHT) family and the proline transporter (ProT) family. AAPs mediate proton-coupled uptake of glutamate (aspartate) and neutral amino acids including proline (Frommer et al. 1993; Fischer et al. 1995, 2002; Okumoto et al. 2002; Lee et al. 2007; Schmidt et al. 2007). The affinity of different AAPs for proline determined in heterologous expression systems varied between 60 and $500 \mu \mathrm{M}$ and was similar to the affinities for other amino acids (Table 1). LHTs transport neutral amino acids (including proline) and acidic amino acids with high affinity (Chen and Bush 1997; Lee and Tegeder 2004; Hirner et al. 2006). Again the affinity of LHTs for proline $\left(K_{\mathrm{m}} \approx 10 \mu \mathrm{M}\right.$; Table 1$)$ was in the same range as the affinity for other amino acids (Hirner et al. 2006). In contrast to transporters of the AAP and LHT family, ProTs transport proline but no other proteinogenic amino acids (Rentsch et al. 1996). Further studies showed that ProTs from Arabidopsis, tomato and the mangrove Avicennia marina also transport glycine betaine, though only the latter is a glycine betaine accumulating species (Breitkreuz et al. 1999; Schwacke et al. 1999; Waditee et al. 2002; Grallath et al. 2005). Furthermore, the three Arabidopsis ProTs and ProT1 of tomato also transport the stressinduced compound $\gamma$-aminobutyric acid (GABA), while GABA was not a substrate for the mangrove proline transporters (AmTs) (Breitkreuz et al. 1999; Schwacke et al. 1999; Waditee et al. 2002; Grallath et al. 2005). Consistent with the latter result, the affinity of the AtProTs for GABA was much lower than for proline or glycine betaine ( $4.5 \mathrm{mM}$ compared to 0.5 and $0.2 \mathrm{mM}$, 
Table 1 Affinity of plant transporters for proline

\begin{tabular}{|c|c|c|c|c|}
\hline Species & Name & $\begin{array}{l}\text { Accession } \\
\text { number }\end{array}$ & $\begin{array}{l}\text { Affinity for } \\
\text { proline }(\mu \mathrm{M})\end{array}$ & Expression pattern \\
\hline
\end{tabular}

ATF/AAAP (amino acid transporter family/amino acid/auxin permease) gene family

ProT proline transporter [substrates: proline, glycine betaine $(\mathrm{GABA})^{\mathrm{a}}$ ]

$\begin{array}{llll}\text { Arabidopsis } & \text { AtProT1 } & \text { At2g39890 } & 427 \pm 17[\text { S.c. }]^{\mathrm{b}} \\ & \text { AtProT2 } & \text { At3g55740 } & 500 \pm 5[\text { S.c. }]^{\mathrm{b}} \\ & & & \\ & \text { AtProT3 } & \text { At2g36590 } & 999 \pm 36[\text { S.c. }]^{\mathrm{b}} \\ \text { Tomato } & \text { LeProT1 } & \text { AF014808 } & 1,900 \pm 260\left[\text { S.c. }{ }^{\mathrm{c}}\right. \\ \text { Barley } & \text { HvProT } & \text { AB073084 } & 25.1[\text { S.c. }]^{\mathrm{d}} \\ \text { Rice } & \text { OsProT } & \text { AB022783 } & \text { a.n.d. }[\text { X.1. }]^{\mathrm{e}} \\ \text { Avicennia marina } & \text { AmT1 } & \text { AB075902 } & 430{\text { [E.c. }]^{\mathrm{f}}}^{\mathrm{f} 0} \\ & \text { AmT2 } & \text { AB075903 } & 320 \text { [E.c. }^{\mathrm{f}}\end{array}$

AAP amino acid permease (substrates: neutral amino acids and glutamate, aspartate ${ }^{\mathrm{a}}$ )

\begin{tabular}{|c|c|c|c|}
\hline \multirow[t]{6}{*}{ Arabidopsis } & AtAAP1 & Atlg58360 & $\begin{array}{l}60\left[^{\text {S.c.c. }}{ }^{\mathrm{g}}\right. \\
1,900[\text { X.1. }]^{\mathrm{h}}\end{array}$ \\
\hline & AtAAP2 & At5g09220 & $140 \pm 20[\text { S.c. }]^{\mathrm{i}}$ \\
\hline & AtAAP3 & At1g77380 & $250 \pm 25[\text { S.c. }]^{\mathrm{j}}$ \\
\hline & AtAAP4 & At5g63850 & $134 \pm 25[\text { S.c. }]^{\mathrm{j}}$ \\
\hline & AtAAP5 & At1g44100 & $500 \pm 25[\text { S.c. }]^{j}$ \\
\hline & AtAAP6 & At5g49630 & $67 \pm 21[\text { S.c. }]^{\mathrm{k}}$ \\
\hline
\end{tabular}

LHT 'lysine/histidine' transporter (substrates: neutral and acidic amino acids ${ }^{\mathrm{a}}$ )

\begin{tabular}{|c|c|c|c|}
\hline Arabidopsis & AtLHT1 & At5g40780 & $10 \pm 0.5[\text { S.c. }]^{1}$ \\
\hline & AtLHT2 & At1g24400 & $13 \pm 3[\text { S.c. }]^{\mathrm{k}}$ \\
\hline
\end{tabular}

APC (amino acid-polyamine-choline) family

CAT cationic amino acid transporters [substrates: neutral and cationic amino acids (lysine) ${ }^{\mathrm{a}}$ ]
Arabidopsis
AtCAT1
At4g21120
$3,000[\text { S.c. }]^{\mathrm{m}}$
Flower, major veins of root and leaf, silique, stem $^{\mathrm{m}}$

Affinities were determined using different heterologous expression systems. Only amino acid transporters for which proline transport was determined are included

[S.c.] Saccharomyces cerevisiae, [X.l.] Xenopus laevis, [E.c.] Escherichia coli, a.n.d. affinity not determined

${ }^{\mathrm{a}}$ Rentsch et al. 2007, ${ }^{\mathrm{b}}$ Grallath et al. 2005, ${ }^{\mathrm{c}} \mathrm{S}$ chwacke et al. 1999, ${ }^{\mathrm{d}}$ Ueda et al. 2001, ${ }^{\mathrm{e}}$ Igarashi et al. 2000, ${ }^{\mathrm{f}}$ Waditee et al. 2002, ${ }^{\mathrm{g}}$ Frommer et al. 1993, hBoorer et al. 1996, ${ }^{\mathrm{i}} \mathrm{K}$ wart et al. 1993, ${ }^{\mathrm{j}}$ Fischer 1997, ${ }^{\mathrm{k}}$ Lee and Tegeder 2004, ${ }^{\mathrm{l}}$ Hirner et al. 2006, ${ }^{\mathrm{m}}$ Frommer et al. 1995, ${ }^{\mathrm{n}}$ Lehmann and Rentsch, unpublished, ${ }^{\circ}$ Rentsch et al. 1996, ${ }^{\mathrm{P}}$ Ueda et al. 2007, ${ }^{\mathrm{q}}$ Fischer et al. 1995, ${ }^{\mathrm{r}}$ Hirner et al. 1998, ${ }^{\mathrm{s}}$ Lee et al. 2007, ${ }^{\mathrm{t}} \mathrm{Sanders}$ et al. 2009, ${ }^{\mathrm{u}}$ Okumoto et al. 2004, ${ }^{\mathrm{v}}$ Okumoto et al. 2002, ${ }^{\mathrm{w}}$ Chen and Bush 1997, ${ }^{\mathrm{x}}$ Foster et al. 2008

respectively Grallath et al. 2005). While the selectivity of rice ProT has not been investigated in detail, barley HvProT recognized only L-proline efficiently, though with a higher affinity than any of the other ProTs (Igarashi et al. 2000; Ueda et al. 2001). These data on substrate selectivity of AAPs, LHTs and ProTs show that in plants both transporters with low and high selectivity for proline exist, indicating a role in general transfer of nitrogen and in proline-specific functions, respectively.
A separation in general amino acid transport and selective proline uptake is also found in the yeast Saccharomyces cerevisiae, where the general amino acid permease Gap $1 p$ and the proline transporter Put $4 p$ together mediate the major part of proline uptake (Lasko and Brandriss 1981). Whereas Gap1p transports all proteinogenic amino acids with low affinity, Put $4 p$ only transports GABA, alanine and glycine in addition to proline and recognizes proline with high affinity (Grenson et al. 1970; 
Lasko and Brandriss 1981; Jauniaux et al. 1987; Regenberg et al. 1999). The amino acid permeases Agp1 and Gnp1p may contribute to residual low affinity proline uptake (Andréasson et al. 2004).

Also in bacteria, the accumulation of compatible solutes is controlled by synthesis, uptake and export, though uptake is preferred over biosynthesis provided that proline or glycine betaine is available (Kempf and Bremer 1998; Roeßler and Müller 2001). A range of secondary active transporters (e.g. the E. coli $\mathrm{H}^{+}$/proline symporter ProP) and binding protein-dependent $\mathrm{ABC}$ transporters (e.g. E. coli $\mathrm{ProU}$ ) mediate the uptake of proline and/or glycine betaine and related substrates (Csonka 1989; Wood et al. 2001). Under osmotic stress, these transporters may be regulated via both increased gene expression and higher activity (Wood et al. 2001), and some were additionally shown to function as osmosensors (Morbach and Krämer 2002; Wood 2006). In addition to osmolyte uptake systems, E. coli uses the PutP transporter for uptake of proline as a nitrogen and carbon source (Csonka 1989). PutP expression is repressed by the trifunctional PutA protein (combining $\mathrm{PDH}, \mathrm{P} 5 \mathrm{CDH}$ and regulatory functions in a single protein) in the absence of proline and becomes activated once the PutA protein is recruited to the membrane during proline degradation (Tanner 2008; Zhou et al. 2008).

The fact that in different kingdoms many transporters that belong to completely different gene families recognize both proline and glycine betaine argues for similarities in substrate recognition. Interestingly, BGT1, a member of the sodium- and chloride-dependent neurotransmitter transporter (SCL6) family in mammals transports GABA, glycine betaine and proline, though proline transport activity was lower (Matskevitch et al. 1999; Chen et al. 2004). Like many of the proline and glycine betaine transporters in bacteria and plants, BGTl-expression is regulated by changes in osmolarity and a role of BGT1 in osmoregulation in kidney was postulated (Chen et al. 2004).

Physiological role of plant proline transporters

So far, all functionally characterized proline transporters operate as cellular uptake systems, whereas information on carrier-mediated export is missing (Rentsch et al. 2007). Using knockout mutants, in planta transport studies confirmed the selectivity determined in heterologous systems (Hirner et al. 2006; Lee et al. 2007; Svennerstam et al. 2007; Näsholm et al. 2009). The complementary though overlapping expression patterns indicate specific physiological functions, but partial redundancy might also be expected. As members of the AAP and LHT families are not selective for proline, they rather play a role in general acquisition and allocation of nitrogen in the plant. Indeed, results from Arabidopsis $l$ thl, aap 8 and aapl mutants as well as overexpression of Vicia faba AAPl in Vicia narbonensis and pea revealed complex and sometimes transient changes in amino acid levels (Rolletschek et al. 2005; Hirner et al. 2006; Schmidt et al. 2007; Weigelt et al. 2008; Sanders et al. 2009). Changes in proline levels in these mutants might also originate from stress-induced alteration of proline metabolism.

The selectivity of ProTs for proline and other compatible solutes indicates a specific role in proline homeostasis under stress and non-stress conditions. Expression analyses supported this function, as ProT expression was generally related to low water availability and/or high proline (or glycine betaine) levels. Under salt stress, proline accumulation is accompanied by an increased expression of Arabidopsis ProT2, mangrove AmT1, 2 and 3 as well as HvProT (Rentsch et al. 1996; Ueda et al. 2001; Waditee et al. 2002; Table 1). Likewise, the high transcript abundance of AtProTl and LeProTl in pollen and of AtProT3 in the epidermis correlated with an elevated proline content (Schwacke et al. 1999; Lehmann and Rentsch, unpublished). AtProTl transcripts were found in different organs in addition to pollen, but expression was confined to the phloem, pointing to a role in long-distance transport (Grallath et al. 2005). Similarly, expression of rice OsProT was detected in all organs analysed (Igarashi et al. 2000; Table 1).

In spite of these correlations, there are only few reports showing a direct role of ProTs in proline transport in planta. The Arabidopsis knockouts mutants atprot1, atprot 2 or atprot 3 did not reveal phenotypic differences or altered proline content in the absence or presence of abiotic stress, indicating compensation by other transporters or altered proline metabolism (Lehmann and Rentsch, unpublished). However, the overexpression of HvProT in Arabidopsis resulted in reduced biomass and decreased proline levels in shoots, an effect that could be compensated by exogenous supply of low concentrations of proline (Ueda et al. 2008). Elevated PDH mRNA and activity in these plants suggested that altered transport may induce proline degradation, leading to a reduction of overall proline content (Ueda et al. 2008). On the other hand, root cap specific expression of HvProT in Arabidopsis resulted in higher proline levels in root tips and enhanced root elongation (Ueda et al. 2008), supporting a role of proline in organ development.

\section{Intracellular transport}

As proline metabolism is confined to distinct cellular compartments (Fig. 1), intracellular transport of proline is required. Proline biosynthesis takes place in the cytosol and probably in chloroplasts under stress conditions (Szabados 
and Savoure 2010). Thus, at least in the absence of stress proline import into plastids is necessary. Furthermore, transfer into mitochondria is essential for proline catabolism. Whereas to our knowledge, information on proline transport into or out of plastids is lacking, proline uptake into mitochondria has been demonstrated to be mediated by two transport systems, i.e. a proline uniporter as well as a proline/glutamate antiport system (Elthon et al. 1984; Di Martino et al. 2006), though a reversible switch of the transport mode as shown for other mitochondrial carriers cannot yet be excluded (Krämer 1998). Likewise, in mammals, a glutamate/proline antiporter was characterized (Atlante et al. 1996). However, no genes encoding intracellular transporters have been identified in plants so far (Picault et al. 2004).

Much information is meanwhile available on proline metabolism and its regulation and compartmentation, but still the various physiological functions proposed for free proline lack mechanistic explanations that are unambiguosly substantiated by experimental evidence. Likewise, the role of proline translocation and the identity of intracellular proline transport systems are still largely unknown. More detailed analyses might reveal novel and interesting links between metabolism and transport, which may contribute to a better understanding of the role and regulation of proline homeostasis.

Acknowledgments We are grateful to the Swiss National Foundation (Grant no. 3100A0-107507), the University of Bern (Switzerland), the University of Konstanz (Germany) and Hungarian Scientific Research Fund (Grant no. K-68226).

\section{References}

Ábrahám E, Rigó G, Székely G, Nagy R, Koncz C, Szabados L (2003) Light-dependent induction of proline biosynthesis by abscisic acid and salt stress is inhibited by brassinosteroid in Arabidopsis. Plant Mol Biol 51:363-372

Amberger-Ochsenbauer S, Obendorfer J (1988) Levels of free proline in ornamental plants: I. Influence of plant age, leaf age, and leaf region in Saintpaulia and Chrysanthemum. J Plant Physiol 132:758-761

Andréasson C, Neve EPA, Ljungdahl PO (2004) Four permeases import proline and the toxic proline analogue azetidine-2carboxylate into yeast. Yeast 21:193-199

Aral B, Kamoun P (1997) The proline biosynthesis in living organisms. Amino Acids 13:189-217

Aral B, Schlenzig JS, Liu G, Kamoun P (1996) Database cloning human $\Delta^{1}$-pyrroline-5-carboxylate synthetase (P5CS) cDNA: a bifunctional enzyme catalyzing the first two steps in proline biosynthesis. C R Acad Sci III 319:171-178

Armengaud P, Thiery L, Buhot N, Grenier-de March G, Savouré A (2004) Transcriptional regulation of proline biosynthesis in Medicago truncatula reveals developmental and environmental specific features. Physiol Plant 120:442-450

Atlante A, Passarella S, Pierro P, Martino C, Quagliariello E (1996) The mechanism of proline/glutamate antiport in rat kidney mitochondria. Eur J Biochem 241:171-177
Ayliffe MA, Mitchell HJ, Deuschle K, Pryor AJ (2005) Comparative analysis in cereals of a key proline catabolism gene. Mol Genet Genomics 274:494-505

Baumgartner MR, Rabier D, Nassogne MC, Dufier JL, Padovani JP, Kamoun P, Valle D, Saudubray JM (2005) $\Delta^{1}$-Pyrroline-5carboxylate synthase deficiency: neurodegeneration, cataracts and connective tissue manifestations combined with hyperammonaemia and reduced ornithine, citrulline, arginine and proline. Eur J Pediatr 164:31-36

Bialczyk J, Lechowski Z, Dziga D (2004) Composition of the xylem sap of tomato seedlings cultivated on media with $\mathrm{HCO}_{3}{ }^{-}$and nitrogen source as $\mathrm{NO}_{3}{ }^{-}$or $\mathrm{NH}_{4}{ }^{+}$. Plant Soil 263:265-272

Bicknell LS, Pitt J, Aftimos S, Ramadas R, Maw MA, Robertson SP (2008) A missense mutation in ALDH18A1, encoding $\Delta^{1}$-pyrroline-5-carboxylate synthase (P5CS), causes an autosomal recessive neurocutaneous syndrome. Eur $\mathrm{J}$ Hum Genet 16:1176-1186

Bock KW, Honys D, Ward JM, Padmanaban S, Nawrocki EP, Hirschi KD, Twell D, Sze H (2006) Integrating membrane transport with male gametophyte development and function through transcriptomics. Plant Physiol 140:1151-1168

Bohnert HJ, Nelson DE, Jensen RG (1995) Adaptations to environmental stresses. Plant Cell 7:1099-1111

Bonner CA, Williams DS, Aldrich HC, Jensen RA (1996) Antagonism by L-glutamine of toxicity and growth inhibition caused by other amino acids in suspension cultures of Nicotiana silvestris. Plant Sci 113:43-58

Boorer KJ, Frommer WB, Bush DR, Kreman M, Loo DDF, Wright EM (1996) Kinetics and specificity of a $\mathrm{H}^{+} /$amino acid transporter from Arabidopsis thaliana. J Biol Chem 271:22132220

Breitkreuz KE, Shelp BJ, Fischer WN, Schwacke R, Rentsch D (1999) Identification and characterization of GABA, proline and quaternary ammonium compound transporters from Arabidopsis thaliana. FEBS Lett 450:280-284

Brugière N, Dubois F, Limami AM, Lelandais M, Roux Y, Sangwan RS, Hirel B (1999) Glutamine synthetase in the phloem plays a major role in controlling proline production. Plant Cell 11:19952012

Carter C, Shafir S, Yehonatan L, Palmer R, Thornburg R (2006) A novel role for proline in plant floral nectars. Naturwissenschaften 93:72-79

Chen L, Bush DR (1997) LHT1, a lysine- and histidine-specific amino acid transporter in Arabidopsis. Plant Physiol 115:1127-1134

Chen NH, Reith MEA, Quick MW (2004) Synaptic uptake and beyond: the sodium- and chloride-dependent neurotransmitter transporter family SLC6. Pflüg Arch Eur J Physiol 447:519-531

Chiang H, Dandekar AM (1995) Regulation of proline accumulation in Arabidopsis thaliana (L.) Heynh during development and in response to desiccation. Plant Cell Environ 18:1280-1290

Csonka LN (1989) Physiological and genetic responses of bacteria to osmotic stress. Microbiol Mol Biol Rev 53:121-147

Csonka LN, Gelvin SB, Goodner BW, Orser CS, Siemieniak D, Slightom JL (1988) Nucleotide sequence of a mutation in the proB gene of Escherichia coli that confers proline overproduction and enhanced tolerance to osmotic stress. Gene 64:199-205

Desikan R, Griffiths R, Hancock J, Neill S (2002) A new role for an old enzyme: nitrate reductase-mediated nitric oxide generation is required for abscisic acid-induced stomatal closure in Arabidopsis thaliana. Proc Natl Acad Sci 99:16314-16318

Deuschle K, Funck D, Hellmann H, Däschner K, Binder S, Frommer WB (2001) A nuclear gene encoding mitochondrial $\Delta^{1}$-pyrroline-5-carboxylate dehydrogenase and its potential role in protection from proline toxicity. Plant J 27:345-355

Deuschle K, Funck D, Forlani G, Stransky H, Biehl A, Leister D, van der Graaff E, Kunze R, Frommer WB (2004) The role of 
$\Delta^{1}$-pyrroline-5-carboxylate dehydrogenase in proline degradation. Plant Cell 16:3413-3425

Di Martino C, Pizzuto R, Pallotta M, De Santis A, Passarella S (2006) Mitochondrial transport in proline catabolism in plants: the existence of two separate translocators in mitochondria isolated from durum wheat seedlings. Planta 223:1123-1133

Donald SP, Sun XY, Hu CAA, Yu J, Mei JM, Valle D, Phang JM (2001) Proline oxidase, encoded by p53-induced gene-6, catalyzes the generation of proline-dependent reactive oxygen species. Cancer Res 61:1810-1815

Dougherty KM, Brandriss MC, Valle D (1992) Cloning human pyrroline-5-carboxylate reductase cDNA by complementation in Saccharomyces cerevisiae. J Biol Chem 267:871-875

El-Tayeb MA (2005) Response of barley grains to the interactive effect of salinity and salicylic acid. Plant Growth Regul 45:215224

Elthon TE, Stewart CR (1982) Proline oxidation in corn mitochondria: involvement of NAD, relationship to ornithine metabolism, and sidedness on the inner membrane. Plant Physiol 70:567-572

Elthon TE, Stewart CR, Bonner WD (1984) Energetics of proline transport in corn mitochondria. Plant Physiol 75:951-955

Fabro G, Kovács I, Pavet V, Szabados L, Alvarez ME (2004) Proline accumulation and AtP5CS2 gene activation are induced by plant-pathogen incompatible interactions in Arabidopsis. Mol Plant Microbe Interact 17:343-350

Finkelstein R, Gampala S, Rock C (2002) Abscisic acid signaling in seeds and seedlings. Plant Cell 14:S15-S45

Fischer WN (1997) Substratspezifität und Transportmechanismus pflanzlicher Aminosäuren in Relation zu ihrer physiologischen Funktion. Dissertation, Eberhard-Karls-University Tübingen, Germany

Fischer WN, Kwart M, Hummel S, Frommer WB (1995) Substrate specificity and expression profile of amino acid transporters (AAPs) in Arabidopsis. J Biol Chem 270:16315-16320

Fischer WN, Loo DDF, Koch W, Ludewig U, Boorer KJ, Tegeder M, Rentsch D, Wright EM, Frommer WB (2002) Low and high affinity amino acid $\mathrm{H}^{+}$-cotransporters for cellular import of neutral and charged amino acids. Plant J 29:717-731

Forlani G, Scainelli D, Nielsen E (1997) Two $\Delta^{1}$-pyrroline-5carboxylate dehydrogenase isoforms are expressed in cultured Nicotiana plumbaginifolia cells and are differentially modulated during the culture growth cycle. Planta 202:242

Foster J, Lee YH, Tegeder M (2008) Distinct expression of members of the LHT amino acid transporter family in flowers indicates specific roles in plant reproduction. Sex Plant Reprod 21:143152

Frommer WB, Hummel S, Riesmeier JW (1993) Expression cloning in yeast of a cDNA encoding a broad specificity amino acid permease from Arabidopsis thaliana. Proc Natl Acad Sci 90:5944-5948

Frommer WB, Hummel S, Unseld M, Ninnemann O (1995) Seed and vascular expression of a high-affinity transporter for cationic amino acids in Arabidopsis. Proc Natl Acad Sci 92:12036-12040

Fujita T, Maggio A, García-Ríos M, Bressan RA, Csonka LN (1998) Comparative analysis of the regulation of expression and structures of two evolutionarily divergent genes for $\Delta^{1}$-pyrroline-5-carboxylate synthetase from tomato. Plant Physiol 118:661-674

Funck D, Stadelhofer B, Koch W (2008) Ornithine- $\delta$-aminotransferase is essential for arginine catabolism but not for proline biosynthesis. BMC Plant Biol 8:40

Gibson SI (2005) Control of plant development and gene expression by sugar signaling. Curr Opin Plant Biol 8:93-102

Ginzberg I, Stein H, Kapulnik Y, Szabados L, Strizhov N, Schell J, Koncz C, Zilberstein A (1998) Isolation and characterization of two different cDNAs of $\Delta^{1}$-pyrroline-5-carboxylate synthase in alfalfa, transcriptionally induced upon salt stress. Plant Mol Biol 38:755-764

Girousse C, Bournoville R, Bonnemain JL (1996) Water deficitinduced changes in concentrations in proline and some other amino acids in the phloem sap of alfalfa. Plant Physiol 111:109 113

Grallath S, Weimar T, Meyer A, Gumy C, Suter-Grotemeyer M, Neuhaus J-M, Rentsch D (2005) The AtProT family. Compatible solute transporters with similar substrate specificity but differential expression patterns. Plant Physiol 137:117-126

Grenson M, Hou C, Crabeel M (1970) Multiplicity of the amino acid permeases in Saccharomyces cerevisiae IV. Evidence for a general amino acid permease. J Bacteriol 103:770-777

Hammes UZ, Nielsen E, Honaas LA, Taylor CG, Schachtman DP (2006) AtCAT6, a sink-tissue-localized transporter for essential amino acids in Arabidopsis. Plant J 48:414-426

Hanson AD, Tully RE (1979) Amino acids translocated from turgid and water-stressed barley leaves: II. Studies with ${ }^{13} \mathrm{~N}$ and ${ }^{14} \mathrm{C}$. Plant Physiol 64:467-471

Hanson J, Hanssen M, Wiese A, Hendriks MMWB, Smeekens S (2008) The sucrose regulated transcription factor bZIP11 affects amino acid metabolism by regulating the expression of Asparagine Synthetase 1 and Proline Dehydrogenase2. Plant J 53:935-949

Hare PD, Cress WA (1996) Tissue-specific accumulation of transcript encoding $\Delta^{1}$-pyrrolline-5-carboxylate reductase in Arabidopsis thaliana. Plant Growth Regul 19:249-256

Hare PD, Cress W, van Staden J (1999) Proline synthesis and degradation: a model system for elucidating stress-related signal transduction. J Exp Bot 50:413-434

Hare PD, Cress WA, van Staden J (2002) Disruptive effects of exogenous proline on chloroplast and mitochondrial ultrastructure in Arabidopsis leaves. S Afr J Bot 68:393-396

Hare PD, Cress WA, van Staden J (2003) A regulatory role for proline metabolism in stimulating Arabidopsis thaliana seed germination. Plant Growth Regul 39:41-50

Hayashi F, Ichino T, Osanai M, Wada K (2000) Oscillation and regulation of proline content by $P 5 C S$ and $P r o D H$ gene expressions in the light/dark cycles in Arabidopsis thaliana L. Plant Cell Physiol 41:1096-1101

Hellmann H, Funck D, Rentsch D, Frommer WB (2000) Hypersensitivity of an Arabidopsis sugar signaling mutant toward exogenous proline application. Plant Physiol 123:779-789

Hien DT, Jacobs M, Angenon G, Hermans C, Thu TT, Son LV, Roosens NH (2003) Proline accumulation and $\Delta^{1}$-pyrroline-5carboxylate synthetase gene properties in three rice cultivars differing in salinity and drought tolerance. Plant Sci 165:10591068

Hirner B, Fischer WN, Rentsch D, Kwart M, Frommer WB (1998) Developmental control of $\mathrm{H}^{+}$/amino acid permease gene expression during seed development of Arabidopsis. Plant J 14:535-544

Hirner A, Ladwig F, Stransky H, Okumoto S, Keinath M, Harms A, Frommer WB, Koch W (2006) Arabidopsis LHT1 is a highaffinity transporter for cellular amino acid uptake in both root epidermis and leaf mesophyll. Plant Cell 18:1931-1946

Honys D, Twell D (2004) Transcriptome analysis of haploid male gametophyte development in Arabidopsis. Genome Biol 5:R85

Horner M, Pratt ML (1979) Amino acid analysis of in vivo and androgenic anthers of Nicotiana tabacum. Protoplasma 98:279282

Hu CA, Delauney AJ, Verma DP (1992) A bifunctional enzyme ( $\Delta^{1}$-pyrroline-5-carboxylate synthetase) catalyzes the first two steps in proline biosynthesis in plants. Proc Natl Acad Sci 89:9354-9358

Hu CA, Lin WW, Obie C, Valle D (1999) Molecular enzymology of mammalian $\Delta^{1}$-pyrroline-5-carboxylate synthase. J Biol Chem 274:6754-6762 
Hu CA, Khalil S, Zhaorigetu S, Liu Z, Tyler M, Wan G, Valle D (2008a) Human $\Delta^{1}$-pyrroline-5-carboxylate synthase: function and regulation. Amino Acids 35:665-672

Hu CA, Bart Williams D, Zhaorigetu S, Khalil S, Wan G, Valle D (2008b) Functional genomics and SNP analysis of human genes encoding proline metabolic enzymes. Amino Acids 35:655-664

Hua XJ, van de Cotte B, van Montagu M, Verbruggen N (1997) Developmental regulation of pyrroline-5-carboxylate reductase gene expression in Arabidopsis. Plant Physiol 114:1215-1224

Hur J, Jung KH, Lee CH, An G (2004) Stress-inducible OsP5CS2 gene is essential for salt and cold tolerance in rice. Plant Sci 167:417-426

Igarashi Y, Yoshiba Y, Takeshita T, Nomura S, Otomo J, YamaguchiShinozaki K, Shinozaki K (2000) Molecular cloning and characterization of a cDNA encoding proline transporter in rice. Plant Cell Physiol 41:750-756

Jauniaux JC, Vandenbol M, Vissers S, Broman K, Grenson M (1987) Nitrogen catabolite regulation of proline permease in Saccharomyces cerevisiae. Eur J Biochem 164:601-606

Joyce PS, Paleg LG, Aspinall D (1984) The requirement for lowintensity light in the accumulation of proline as a response to water deficit. J Exp Bot 35:209-218

Kanade M (2008) Effect of foliar application of salicylic acid on polyphenol, proline and carbohydrates content in wheat and sorghum. Adv Plant Sci 21:321-322

Kavi Kishor PB, Hong Z, Miao GH, Hu CAA, Verma DPS (1995) Overexpression of $\Delta^{1}$-pyrroline-5-carboxylate synthetase increases proline production and confers osmotolerance in transgenic plants. Plant Physiol 108:1387-1394

Kavi Kishor PB, Sangam S, Amrutha RN, Sri Laxmi P, Naidu KR, Rao KRSS, Rao S, Reddy KJ, Theriappan P, Sreenivasulu N (2005) Regulation of proline biosynthesis, degradation, uptake and transport in higher plants: its implications in plant growth and abiotic stress tolerance. Curr Sci 88:424-438

Kempf B, Bremer E (1998) Uptake and synthesis of compatible solutes as microbial stress responses to high-osmolality environments. Arch Microbiol 170:319-330

Khan W, Prithiviraj B, Smith DL (2003) Photosynthetic responses of corn and soybean to foliar application of salicylates. J Plant Physiol 160:485-492

Khodary SEA (2004) Effect of salicylic acid on the growth, photosynthesis and carbohydrate metabolism in salt-stressed maize plants. Int J Agr Biol 6:5-8

Khoo U, Stinson HT (1957) Free amino acid differences between cytoplasmic male sterile and normal fertile anthers. Proc Natl Acad Sci 43:603-607

Kiyosue T, Yoshiba Y, Yamaguchi-Shinozaki K, Shinozaki K (1996) A nuclear gene encoding mitochondrial proline dehydrogenase, an enzyme involved in proline metabolism, is upregulated by proline but downregulated by dehydration in Arabidopsis. Plant Cell 8:1323-1335

Krämer R (1998) Mitochondrial carrier proteins can reversibly change their transport mode: the cases of the aspartate/glutamate and the phosphate carrier. Exp Physiol 83:259-265

Krogaard H, Andersen AS (1983) Free amino acids of Nicotiana alata anthers during development in vivo. Physiol Plant 57:527-531

Kwart M, Hirner B, Hummel S, Frommer WB (1993) Differential expression of two related amino acid transporters with differing substrate specificity in Arabidopsis thaliana. Plant J 4:993-1002

Lansac AR, Sullivan CY, Johnson BE (1996) Accumulation of free proline in sorghum (Sorghum bicolor) pollen. Can J Bot 74:40-45

Larher F, Leport L, Petrivalsky M, Chappart M (1993) Effectors for the osmoinduced proline response in higher plants. Plant Physiol Biochem 31:911-922

Lasko PF, Brandriss MC (1981) Proline transport in Saccharomyces cerevisiae. J Bacteriol 148:241-247
Lee YH, Tegeder M (2004) Selective expression of a novel highaffinity transport system for acidic and neutral amino acids in the tapetum cells of Arabidopsis flowers. Plant J 40:60-74

Lee YH, Foster J, Chen J, Voll LM, Weber APM, Tegeder M (2007) AAP1 transports uncharged amino acids into roots of Arabidopsis. Plant J 50:305-319

López-Carrión A, Castellano R, Rosales M, Ruiz J, Romero L (2008) Role of nitric oxide under saline stress: implications on proline metabolism. Biol Plant 52:587-591

Madan S, Nainawatee H, Jain S, Jain R, Malik M, Chowdhury J (1994) Leaf position-dependent changes in proline, pyrroline-5carboxylate reductase activity and water relations under saltstress in genetically stable salt-tolerant somaclones of Brassica juncea L. Plant Soil 163:151-156

Mani S, Van de Cotte B, Van Montagu M, Verbruggen N (2002) Altered levels of proline dehydrogenase cause hypersensitivity to proline and its analogs in Arabidopsis. Plant Physiol 128:73-83

Martínez C, Pons E, Prats G, León J (2004) Salicylic acid regulates flowering time and links defence responses and reproductive development. Plant J 37:209-217

Mascarenhas JP (1993) Molecular mechanisms of pollen tube growth and differentiation. Plant Cell 5:1303-1314

Matskevitch I, Wagner CA, Stegen C, Bröer S, Noll B, Risler T, Kwon HM, Handler JS, Waldegger S, Busch AE, Lang F (1999) Functional characterization of the betaine $/ \gamma$-aminobutyric acid transporter BGT-1 expressed in Xenopus oocytes. J Biol Chem 274:16709-16716

Mattioli R, Marchese D, D'Angeli S, Altamura M, Costantino P, Trovato M (2008) Modulation of intracellular proline levels affects flowering time and inflorescence architecture in Arabidopsis. Plant Mol Biol 66:277-288

Mattioli R, Costantino P, Trovato M (2009a) Proline accumulation in plants: not only stress. Plant Signal Behav 4:1016-1018

Mattioli R, Falasca G, Sabatini S, Altamura MM, Costantino P, Trovato M (2009b) The proline biosynthetic genes P5CS1 and P5CS2 play overlapping roles in Arabidopsis flower transition but not in embryo development. Physiol Plant 137:72-85

Mauro ML, Trovato M, Paolis AD, Gallelli A, Costantino P, Altamura MM (1996) The plant oncogene rolD stimulates flowering in transgenic tobacco plants. Dev Biol 180:693-700

Meinke D, Muralla R, Sweeney C, Dickerman A (2008) Identifying essential genes in Arabidopsis thaliana. Trends Plant Sci 13:483-491

Miller G, Honig A, Stein H, Suzuki N, Mittler R, Zilberstein A (2009) Unraveling $\Delta^{1}$-pyrroline-5-carboxylate-proline cycle in plants by uncoupled expression of proline oxidation enzymes. J Biol Chem 284:26482-26492

Misra N, Saxena P (2009) Effect of salicylic acid on proline metabolism in lentil grown under salinity stress. Plant Sci 177:181-189

Mitchell HJ, Ayliffe MA, Rashid KY, Pryor AJ (2006) A rustinducible gene from flax $(f i s 1)$ is involved in proline catabolism. Planta 223:213-222

Mitsubuchi H, Nakamura K, Matsumoto S, Endo F (2008) Inborn errors of proline metabolism. J Nutr 138:2016S-2020S

Morbach S, Krämer R (2002) Body shaping under water stress: osmosensing and osmoregulation of solute transport in Bacteria. ChemBioChem 3:384-397

Murahama M, Yoshida T, Hayashi F, Ichino T, Sanada Y, Wada K (2001) Purification and characterization of $\Delta^{1}$-pyrroline-5-carboxylate reductase isoenzymes indicating differential distribution in spinach (Spinacia oleracea L.) leaves. Plant Cell Physiol 42:742-750

Mutters RG, Ferreira LGR, Hall AE (1989) Proline content of the anthers and pollen of heat-tolerant and heat-sensitive cowpea subjected to different temperatures. Crop Sci 29:1497-1500 
Nakashima K, Satoh R, Kiyosue T, Yamaguchi-Shinozaki K, Shinozaki K (1998) A gene encoding proline dehydrogenase is not only induced by proline and hypoosmolarity, but is also developmentally regulated in the reproductive organs of Arabidopsis. Plant Physiol 118:1233-1241

Nanjo T, Kobayashi M, Yoshiba Y, Sanada Y, Wada K, Tsukaya H, Kakubari Y, Yamaguchi-Shinozaki K, Shinosaki K (1999) Biological functions of proline in morphogenesis and osmotolerance revealed in antisense transgenic Arabidopsis thaliana. Plant J 18:185-193

Nanjo T, Fujita M, Seki M, Kato T, Tabata S, Shinozaki K (2003) Toxicity of free proline revealed in an Arabidopsis T-DNAtagged mutant deficient in proline dehydrogenase. Plant Cell Physiol 44:541-548

Näsholm T, Kielland K, Ganeteg U (2009) Uptake of organic nitrogen by plants. New Phytol 182:31-48

Neill S, Barros R, Bright J, Desikan R, Hancock J, Harrison J, Morris P, Ribeiro D, Wilson I (2008) Nitric oxide, stomatal closure, and abiotic stress. J Exp Bot 59:165-176

Nepi M, von Aderkas P, Wagner R, Mugnaini S, Coulter A, Pacini E (2009) Nectar and pollination drops: how different are they? Ann Bot 104:205-219

Okumoto S, Schmidt R, Tegeder M, Fischer WN, Rentsch D, Frommer WB, Koch W (2002) High affinity amino acid transporters specifically expressed in xylem parenchyma and developing seeds of Arabidopsis. J Biol Chem 277:4533845346

Okumoto S, Koch W, Tegeder M, Fischer WN, Biehl A, Leister D, Stierhof YD, Frommer WB (2004) Root phloem-specific expression of the plasma membrane amino acid proton cotransporter AAP3. J Exp Bot 55:2155-2168

Ötztürk L, Demir Y (2002) In vivo and in vitro protective role of proline. Plant Growth Regul 38:259-264

Pancheva TV, Popova LP, Uzunova AN (1996) Effects of salicylic acid on growth and photosynthesis in barley plants. J Plant Physiol 149:57-63

Peng Z, Lu Q, Verma DPS (1996) Reciprocal regulation of $\Delta^{1}$-pyrroline-5-carboxylate synthetase and proline dehydrogenase genes controls proline levels during and after osmotic stress in plants. Mol Gen Genet 253:334-341

Pesci P (1993) Glucose mimics the enhancing effect of light on ABAinduced proline accumulation in hydrated barley and wheat leaves. J Plant Physiol 142:355-359

Phang J, Donald S, Pandhare J, Liu Y (2008) The metabolism of proline, a stress substrate, modulates carcinogenic pathways. Amino Acids 35:681-690

Picault N, Hodges M, Palmieri L, Palmieri F (2004) The growing family of mitochondrial carriers in Arabidopsis. Trends Plant Sci 9:138-146

Ramesh V, Gusella JF, Shih VE (1991) Molecular pathology of gyrate atrophy of the choroid and retina due to ornithine aminotransferase deficiency. Mol Biol Med 8:81-93

Raymond MJ, Smirnoff N (2002) Proline metabolism and transport in maize seedlings at low water potential. Ann Bot 89:813-823

Regenberg B, Düring-Olsen L, Kielland-Brandt MC, Holmberg S (1999) Substrate specificity and gene expression of the aminoacid permeases in Saccharomyces cerevisiae. Curr Genet 36:317-328

Rentsch D, Hirner B, Schmelzer E, Frommer WB (1996) Salt stressinduced proline transporters and salt stress-repressed broad specificity amino acid permeases identified by suppression of a yeast amino acid permease-targeting mutant. Plant Cell 8:14371446

Rentsch D, Schmidt S, Tegeder M (2007) Transporters for uptake and allocation of organic nitrogen compounds in plants. FEBS Lett 581:2281-2289
Reversade B, Escande-Beillard N, Dimopoulou A et al (2009) Mutations in PYCRI cause cutis laxa with progeroid features. Nat Genet 41:1016-1021

Ribarits A, Abdullaev A, Tashpulatov A, Richter A, Heberle-Bors E, Touraev A (2007) Two tobacco proline dehydrogenases are differentially regulated and play a role in early plant development. Planta 225:1313-1324

Roeßler M, Müller V (2001) Osmoadaptation in bacteria and archaea: common principles and differences. Environ Microbiol 3:743-754

Rolletschek H, Hosein F, Miranda M, Heim U, Gotz KP, Schlereth A, Borisjuk L, Saalbach I, Wobus U, Weber H (2005) Ectopic expression of an amino acid transporter (VfAAP1) in seeds of Vicia narbonensis and pea increases storage proteins. Plant Physiol 137:1236-1249

Rook F, Gerrits N, Kortstee A, van Kampen M, Borrias M, Weisbeek P, Smeekens S (1998) Sucrose-specific signalling represses translation of the Arabidopsis ATB2 bZIP transcription factor gene. Plant J 15:253-263

Samach A, Onouchi H, Gold SE, Ditta GS, Schwarz-Sommer Z, Yanofsky MF, Coupland G (2000) Distinct roles of CONSTANS target genes in reproductive development of Arabidopsis. Science 288:1613-1616

Sanada Y, Ueda H, Kuribayashi K, Andoh T, Hayashi F, Tamai N, Wada K (1995) Novel light-dark change of proline levels in halophyte (Mesembryanthemum crystallinum L.) and glycophytes (Hordeum vulgare L. and Triticum aestivum L.) leaves and roots under salt stress. Plant Cell Physiol 36:965-970

Sánchez E, López-Lefebre LR, García PC, Rivero RM, Ruiz JM, Romero L (2001) Proline metabolism in response to highest nitrogen dosages in green bean plants (Phaseolus vulgaris L. cv. Strike). J Plant Physiol 158:593-598

Sánchez E, García PC, López-Lefebre LR, Rivero RM, Ruiz JM, Romero L (2002) Proline metabolism in response to nitrogen deficiency in French Bean plants (Phaseolus vulgaris L. cv Strike). Plant Growth Regul 36:261-265

Sanders A, Collier R, Trethewy A, Gould G, Sieker R, Tegeder M (2009) AAP1 regulates import of amino acids into developing Arabidopsis embryos. Plant J 59:540-552

Satoh R, Nakashima K, Seki M, Shinozaki K, Yamaguchi-Shinozaki K (2002) ACTCAT, a novel cis-acting element for proline- and hypoosmolarity-responsive expression of the $\mathrm{ProDH}$ gene encoding proline dehydrogenase in Arabidopsis. Plant Physiol 130:709719

Satoh R, Fujita Y, Nakashima K, Shinozaki K, Yamaguchi-Shinozaki $\mathrm{K}$ (2004) A novel subgroup of bZIP proteins functions as transcriptional activators in hypoosmolarity-responsive expression of the ProDH gene in Arabidopsis. Plant Cell Physiol 45:309-317

Savouré A, Hua XJ, Bertauche N, van Montagu M, Verbruggen N (1997) Abscisic acid-independent and abscisic acid-dependent regulation of proline biosynthesis following cold and osmotic stresses in Arabidopsis thaliana. Mol Gen Genet 254:104-109

Saxena S, Kaushik N, Sharma R (2008) Effect of abscisic acid and proline on in vitro flowering in Vigna aconitifolia. Biol Plant 52:181-183

Schmidt R, Stransky H, Koch W (2007) The amino acid permease AAP8 is important for early seed development in Arabidopsis thaliana. Planta 226:805-813

Schwacke R, Grallath S, Breitkreuz KE, Stransky E, Stransky H, Frommer WB, Rentsch D (1999) LeProT1, a transporter for proline, glycine betaine, and $\gamma$-amino butyric acid in tomato pollen. Plant Cell 11:377-392

Sekine T, Kawaguchi A, Hamano Y, Takagi H (2007) Desensitization of feedback inhibition of the Saccharomyces cerevisiae $\gamma$-glutamyl kinase enhances proline accumulation and freezing tolerance. Appl Environ Microbiol 73:4011-4019 
Sleator RD, Hill C (2002) Bacterial osmoadaptation: the role of osmolytes in bacterial stress and virulence. FEMS Microbiol Rev 26:49-71

Steber CM, McCourt P (2001) A role for brassinosteroids in germination in Arabidopsis. Plant Physiol 125:763-769

Stewart CR, Morris CJ, Thompson JF (1966) Changes in amino acid content of excised leaves during incubation. III. Role of sugar in the accumulation of proline in wilted leaves. Plant Physiol 41:1585-1590

Stines AP, Naylor DJ, Høj PB, van Heeswijck R (1999) Proline accumulation in developing grapevine fruit occurs independently of changes in the levels of $\Delta^{1}$-pyrroline-5-carboxylate synthetase mRNA or protein. Plant Physiol 120:923-931

Stránská J, Kopečný D, Tylichowá M, Snégaroff J, Šebela M (2008) Ornithine $\delta$-aminotransferase: an enzyme implicated in salt tolerance in higher plants. Plant Signal Behav 3:929-935

Strizhov N, Ábrahám E, Ökrész L, Blickling S, Zilberstein A, Schell J, Koncz C, Szabados L (1997) Differential expression of two P5CS genes controlling proline accumulation during salt-stress requires $\mathrm{ABA}$ and is regulated by $A B A 1, A B I 1$ and $A X R 2$ in Arabidopsis. Plant J 12:557-569

$\mathrm{Su}$ YH, Frommer WB, Ludewig U (2004) Molecular and functional characterization of a family of amino acid transporters from Arabidopsis. Plant Physiol 136:3104-3113

Svennerstam H, Ganeteg U, Bellini C, Näsholm T (2007) Comprehensive screening of Arabidopsis mutants suggests the lysine histidine transporter 1 to be involved in plant uptake of amino acids. Plant Physiol 143:1853-1860

Szabados L, Savouré A (2010) Proline: a multifunctional amino acid. Trends Plant Sci 15:89-97

Székely G, Ábrahám E, Cséplő Á, Rigó G, Zsigmond L, Csiszár J, Ayaydin F, Strizhov N, Jásik J, Schmelzer E, Koncz C, Szabados L (2008) Duplicated P5CS genes of Arabidopsis play distinct roles in stress regulation and developmental control of proline biosynthesis. Plant J 53:11-28

Tanner J (2008) Structural biology of proline catabolism. Amino Acids 35:719-730

Tomenchok DM, Brandriss MC (1987) Gene-enzyme relationships in the proline biosynthetic pathway of Saccharomyces cerevisiae. J Bacteriol 169:5364-5372

Trovato M, Maras B, Linhares F, Costantino P (2001) The plant oncogene rolD encodes a functional ornithine cyclodeaminase. Proc Natl Acad Sci 98:13449-13453

Tully RE, Hanson AD, Nelsen CE (1979) Proline accumulation in water-stressed barley leaves in relation to translocation and the nitrogen budget. Plant Physiol 63:518-523

Turchetto-Zolet A, Margis-Pinheiro M, Margis R (2009) The evolution of pyrroline-5-carboxylate synthase in plants: a key enzyme in proline synthesis. Mol Genet Genomics 281:87-97

Ueda A, Shi W, Sanmiya K, Shono M, Takabe T (2001) Functional analysis of salt-inducible proline transporter of barley roots. Plant Cell Physiol 42:1282-1289

Ueda A, Yamamoto-Yamane Y, Takabe T (2007) Salt stress enhances proline utilization in the apical region of barley roots. Biochem Biophys Res Commun 355:61-66

Ueda A, Shi W, Shimada T, Miyake H, Takabe T (2008) Altered expression of barley proline transporter causes different growth responses in Arabidopsis. Planta 227:277-286

Venekamp JH, Koot JTM (1984) The distribution of free amino acids, especially of proline, in the organs of field bean plants. Vicia faba L., during development in the field. J Plant Physiol 116:343-349

Verbruggen N, Hermans C (2008) Proline accumulation in plants: a review. Amino Acids 35:753-759

Verbruggen N, Villarroel R, Van Montagu M (1993) Osmoregulation of a pyrroline-5-carboxylate reductase gene in Arabidopsis thaliana. Plant Physiol 103:771-781
Verbruggen N, Hua XJ, May M, Van Montagu M (1996) Environmental and developmental signals modulate proline homeostasis: evidence for a negative transcriptional regulator. Proc Natl Acad Sci 93:8787-8791

Verslues PE, Bray EA (2006) Role of abscisic acid (ABA) and Arabidopsis thaliana ABA-insensitive loci in low water potentialinduced ABA and proline accumulation. J Exp Bot 57:201-212

Verslues PE, Sharp RE (1999) Proline accumulation in maize (Zea mays L.) primary roots at low water potentials. II. Metabolic source of increased proline deposition in the elongation zone. Plant Physiol 119:1349-1360

Waditee R, Hibino T, Tanaka Y, Nakamura T, Incharoensakdi A, Hayakawa S, Suzuki S, Futsuhara Y, Kawamitsu Y, Takabe T, Takabe $\mathrm{T}$ (2002) Functional characterization of betaine/proline transporters in betaine-accumulating mangrove. J Biol Chem 277:18373-18382

Wang P, Song CP (2008) Guard-cell signalling for hydrogen peroxide and abscisic acid. New Phytol 178:703-718

Weibull J, Ronquist F, Brishammar S (1990) Free amino acid composition of leaf exudates and phloem sap: a comparative study in oats and barley. Plant Physiol 92:222-226

Weigelt K, Küster H, Radchuk R, Müller M, Weichert H, Fait A, Fernie AR, Saalbach I, Weber H (2008) Increasing amino acid supply in pea embryos reveals specific interactions of $\mathrm{N}$ and $\mathrm{C}$ metabolism, and highlights the importance of mitochondrial metabolism. Plant J 55:909-926

Weltmeier F, Ehlert A, Mayer CS, Dietrich K, Wang X, Schütze K, Alonso R, Harter K, Vicente-Carbajosa J, Dröge-Laser W (2006) Combinatorial control of Arabidopsis proline dehydrogenase transcription by specific heterodimerisation of bZIP transcription factors. EMBO 25:3133-3143

Williamson CL, Slocum RD (1992) Molecular cloning and evidence for osmoregulation of the $\Delta^{1}$-pyrroline-5-carboxylate reductase (proC) gene in pea (Pisum sativum L.). Plant Physiol 100:14641470

Wood JM (2006) Osmosensing by bacteria. Sci STKE 357:pe43

Wood JM, Bremer E, Csonka LN, Kraemer R, Poolman B, van der Heide T, Smith LT (2001) Osmosensing and osmoregulatory compatible solute accumulation by bacteria. Comp Biochem Physiol A Mol Integr Physiol 130:437-460

Yang SL, Lan SS, Gong M (2009) Hydrogen peroxide-induced proline and metabolic pathway of its accumulation in maize seedlings. J Plant Physiol 166:1694-1699

Yoon KA, Nakamura Y, Arakawa H (2004) Identification of ALDH4 as a p53-inducible gene and its protective role in cellular stresses. J Hum Genet 49:134-140

Yusuf M, Syed Aiman H, Barket A, Shamsul H, Qazi F, Aqil A (2008) Effect of salicylic acid on salinity-induced changes in Brassica juncea. J Integr Plant Biol 50:1096-1102

Zhang HQ, Croes AF (1983) Proline metabolism in pollen: degradation of proline during germination and early tube growth. Planta 159:46-49

Zhang LP, Mehta SK, Liu ZP, Yang ZM (2008) Copper-induced proline synthesis is associated with nitric oxide generation in Chlamydomonas reinhardtii. Plant Cell Physiol 49:411-419

Zhao MG, Chen L, Zhang LL, Zhang WH (2009) Nitric reductasedependent nitric oxide production is involved in cold acclimation and freezing tolerance in Arabidopsis. Plant Physiol 151:755767

Zhou Y, Zhu W, Bellur PS, Rewinkel D, Becker DF (2008) Direct linking of metabolism and gene expression in the proline utilization A protein from Escherichia coli. Amino Acids 35:711-718

Zúñiga G, Argandoña VH, Corcuera LJ (1989) Distribution of glycine-betaine and proline in water stressed and unstressed barley leaves. Phytochemistry 28:419-420 